\title{
THEMATIC PROGRESSION IN TEXT ORGANIZATION FROM A NEW PERSPECTIVE: TWO CASES IN ENGLISH AND TURKISH ${ }^{1}$
}

\author{
Zana YALÇINKAYA ${ }^{2}$, Huseynaga RZAYEV ${ }^{3}$
}

\begin{abstract}
There is no doubt that texts are one of the significant vehicles providing communication among people. Unlike the traditional knowledge, texts are not only considered as written. Every item maintaining the communication can be regarded as text. Not only a small hand sign can be regarded as text but also a book consisting of hundreds of pages as well can be accepted as text. Considering the written texts, although some texts are composed of a few sentences, others, however, are composed of hundreds of pages. Therefore, belles-lettres as well is one of text examples. More than that, in the formation of long written texts, thematic progression has been a debatable issue for centuries.In this paper, thematic progression is dealt with and tried to be explained with short story examples taken from Aziz Nesin and O. Wilde.
\end{abstract}

Keywords: Text, Thematic Progress, Information Status, Theme, Rheme.

Yalçınkaya, Zana ve Rzayev Huseynaga. "Thematic Progression in Text Organization from a New Perspective: Two Cases in English and Turkish". idil 6.29 (2017): 233-245.

Yalçınkaya, Z. ve Rzayev H. (2017). Thematic Progression in Text Organization from a New Perspective: Two Cases in English and Turkish. idil, 6 (29), s.233-245.

\footnotetext{
${ }^{1}$ This paper has been derived from the dissertation titled Textuality in English and Turkish. (Suleyman Demirel University, Institute of Social Sciences, Unpublished, 2016)

${ }^{2}$ Instructor, Dicle University Z.G. Education Faculty, zanaykaya(at)gmail.com

${ }^{3}$ Prof. Dr., Suleyman Demirel University, Western Languages and Literature
} 


\title{
TEKST OLUŞUMUNDA TEMATIK ILERLEMEYE YENI BIIR BAKIŞ AÇISI: INGILIZCE VE TÜRKÇE IKI ÖRNEK
}

\begin{abstract}
öz
Tekstler, şüphesiz ki insanlar arasında iletişimi sağlayan önemli araçlardan biri olagelmiştir. Bilinenin aksine, tekstler yalnızca yazılı olarak kabul edilmezler. İletişimi sağlayan her unsur tekst olarak kabul edilebilir. Sadece küçük bir el hareketi değil aynı zamanda yüzlerce sayfadan oluşan bir kitap da tekst olarak kabul edilir. Yazılı tekstler göz önüne alındığında, bazı tekstler birkaç cümleden oluşmasına rağmen bazılar ise yüzlerce sayfadan oluşur. Bundan dolayı, edebî eserler de birer tekst örnekleridir. Bunun yanı sıra, yazılı uzun tekstlerin oluşumunda, tematik ilerleme de yüzyıllarca süregelen bir tartışma konusu olmuştur.Bu makalede tematik ilerleme, Aziz Nesin ve Oscar Wilde'dan alınan kısa öyküler incelenerek açıklanmaya çalışılmıştır.
\end{abstract}

Anahtar Kelimeler: Tekst, Tematik İlerleme, Bilgi Durumu, Theme, Rheme. 


\section{Introduction}

Considering ambiguity in the terminology from the perspective of linguistics, it will be accurate to investigate the terms concerning text, textuality and thematic progression before dealing with thematic progression in text organization. In the Encyclopedia of Language and Linguistics, "the term 'text' derives from the Latin verb texere 'to weave' (hence the resemblance between the words 'text' and 'textile')." Conventionally "a text is defined as that part of a work that is distinguished from the parts which are interconnected and related to the whole (i.e., the text)." (Brown et al, 2005: 598-599). According to Werlich, text is defined as, "A text is an extended structure of syntactic units [i.e., text as super-sentence] such as words, groups, and clauses and textual units that is marked by both coherence among the elements and completion" (1976: 23). For Halliday \& Hasan, text is:

\footnotetext{
[A term] used in linguistics to refer to any passage- spoken or written, of whatever length, that does form a unified whole [....] A text is a unit of language in use. It is not a grammatical unit, like a clause or a sentence; and it is not defined by its size [.... A text is best regarded as a semantic unit; a unit not of form but of meaning (1976: 1-2).
}

Halliday \& Hasan (1976) maintain the significance of language as a medium of social communication. The diversity of the definitions is quite noticeable. It is mostly due to the multidimensional feature of text.

For de Beaugrande and Dressler (1981: 3) a text, "as a communicative occurrence should meet some standards in order to form textuality." Beaugrande and Dressler attempting to distinguish some standards to form a unified and meaningful text set up some criteria of textuality. Accordingly, all these requirements must be met for a communicative text. These communicative features are on the one hand cohesion, coherence, both of which are text centered, and on the other hand, acceptability, intentionality, informativity, situationality and as well as intertextuality which are usercentered. These standards operate as the constitutive principles which enable text to function as a relevant unit of communication.

Sanders \& Sanders (2006: 1075) argue that "A text is more than a random set of utterances: it shows connectedness." Thus, to characterize this connectedness is an essential goal. Conventionally, linguists' approach to this issue has been restricted to analyzing discernible linguistic devices and clear structures as well as describing textuality mainly by means of cohesive devices.

Jacques Derrida, a leading post-structuralist shed a new light on text and textuality. According to the deconstructive theory: 
Textuality is the repository of binary oppositions (signifier/signified, presence/absence, literal/figural), of segments of reasoning, of words that are all informed by radical rhetorical and logical incoherencies that cannot be assimilated into a textual harmony or unity. These signifying incompatibilities reveal to the text itself the characteristics of its own difference (quoted in Colilli, 2006: 640).

Apart from the definitions above-mentioned, it is possible to encounter various definitions related to text and textuality. Each of these terms emphasizes a different characteristics of text and textuality. From a wider perspective, together with these definitions, textuality can be regarded as a product of language-in-use in respect to (a) the 3 level approach to interclausal/intersentential relations; (b) the interplay of grammatical, semantic and communicative levels in text organization. In this study, while investigating thematic progression in text organization, the wider explanation of textuality has been taken into consideration.

Given the definitions concerning text and textuality, thematic progression in text organization as well should be taken into consideration. In this context, first of all, the notions of Arnold, J. E., et al (2013: 403-413) should be considered:

\footnotetext{
People talk for a reason. They want to share news, connect with others, inform, amuse, or cause things to happen. Human languages are organized in ways that reflect the content and purpose of utterances - that is, the information that is contained in the words and structures that make up sentences. This organization is called information structure.
}

Rzayev (2007: 173) argues that word order consists of (a) attempts to emphasize a particular perspective toward language (functional versus structural) which is tied to a focus on "language in use" and (b) the analysis of the common conditions of the communicative use of word-order in various patterns. Word order constructs sentence structures and thus conveys meanings. Interplaying functions of word order stimulates sentence formations in various ways. Therefore, various patterns of word order can be understood by reference to the role that they play both in grammatical and communicative organization of the sentence as a whole.

Ward \& Birner (2006: 302) define information status as "the degree of familiarity of some sub-propositional element-that is, an element which is a part of a larger proposition." Therefore, those mentioned sub-propositional elements may be articulated as any part of speech. However some subpropositional elements may be the whole proposition within another proposition. Consider this (Ward \& Birner, 2006: 303): guessed."

"Philip knew Mary loved him. That she was also jealous of him he had never

In this example, the preposed element that she was also jealous of him indicates the entire proposition. This proposition represents the previously given Mary loved him. 
Thematic progression contains various approaches. Many linguistic choices reflect a distinction between given information (i.e. previously known or discussed) and new information. In introduction of information in a discourse, given information, i.e., known information tends to precede the new information. This flow of information is provided by means of utilizing noncanonical constructions, in other words, syntactic formulations, reorganizing the canonical order of elements i.e., the subject-verb-object in English.

Theories definitely differ. However, it appears that all terminologies have some aspects in common. For example, at least they take into consideration one of these characteristics: (i) a "topic/ comment" or "theme/rheme" discrepancy associates the utterance to the discourse goal, and concentrates on the part that develops the discourse; (ii) a "background/contrast" or "given/new" discrepancy, in terms of the contribution of sentence elements to purposive communication. Theme/rheme structures have been characterized by various scholars.

From the perspective of what has been described above; topic, theme, background and given stand for previously known information, in other words, the less important information; on the other hand, comment, rheme, contrast and new emphasize the new information, i.e., the important information.

The Prague School Circle takes up Communicative Dynamism (CD) to account for information structure. The scholars of this school provide that Communicative Dynamism establishes the linear arrangement of syntactic elements within sentences. In other words, the degree of CD of a constituent in a sentence is the extent to which it puts forward the communication, i.e., the constituent with least CD precedes the ones that have more $\mathrm{CD}$. The theme or topic is viewed with the least $\mathrm{CD}$, the rheme, however, is regarded as predicated of the theme or topic. However, it should be kept in mind that information structure not only plays a role in establishing word order. Interplay of the semantic elements, word order, and CD determine the meaning in a sentence.

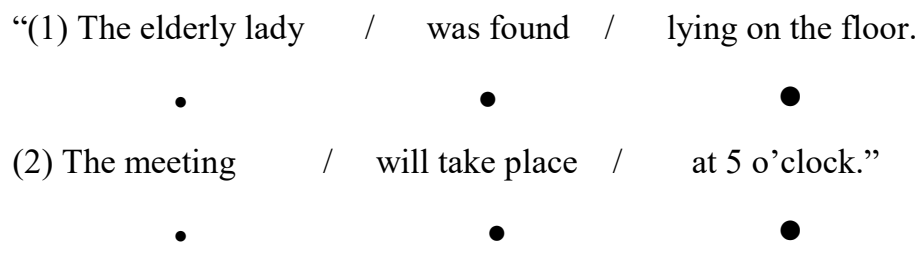

Adam (2007: 22) in the examples above maintain that the linear rise of the degrees of CD from the beginning to the end of the sentence is given. The size of the dots indicates the gradual rise. As Firbas maintains this is the basic distribution of the 
degrees of CD. It is possible to see this linear modification in most of Indo-European languages, albeit in various extent. The significant word order principle in English is provided by the grammatical principle, i.e., the word order of subject, verb, object, adverbial, in other words, the individual sentence elements have to follow their syntactic functions.

From the perspective of thematic progression, even though the structuring of information in English seems to be challenging, nevertheless some generalizations are possible in terms of the givennes and newness. However, unlike the conventional approach, we have attempted a new analysis of the information structure of the following sentence:

"Last night the moon was so pretty that I called a friend on the phone and told him to go outside and look."

Prince argues that while the moon here symbolizes discourse-new information, on the other hand, it is hearer-old information, emphasizing an item which has not been recalled in the previous context. However, it is considered previous knowledge to the hearer. A friend illustrates information which is discourse-new and hearer-new. It has not been recalled in the earlier context and is apparently unknown to the hearer. Him symbolizes discourse-old information and thus hearer-old information, which has been recalled in the previous clause (as a friend). As for the inferable information, i.e., the phone, as generally accepted that people have phones is an unsettled issue for Prince (quoted in Schiffrin et al., 2001: 121). This interpretation does not hold for the following reasons: As the meanings of linguistic units are frequently formulated under the external factors (in this case, the uniqueness of the moon is the basic factor to consider it as not only familiar but completely "known"), "the moon" cannot symbolize any discoursenew information. The other debatable problem lies in the partition of the main clause into the so-called "old" and "new" information parts, "was so pretty" is the discoursenew (motivated) what, in fact, is the principal purpose of this clause. More than that, the intensifier "so" is an evident semantic constraint enhancing the strength of the purposive aspect of the new information.

Many languages employ various expressions for information structure. In English, the tendency is to place given information before new information. In Turkish as well, it is also similar. However, considering the example above, in some cases thematic progression does not hold in line with word order. Theme/Rheme and the others do not go in line with word order. In another example,

“1-) I have bought a new car. S - V - O unmarked

Rheme

2-) A pretty girl entered the room." $\mathrm{S}-\mathrm{V}$ - unmarked Rheme 
Native speakers of English consider the example (1) as unmarked. It should be noted that as Firbas (1992) argues "in English the marked flavour consists in the deviation from the grammatical word order." In other words, in English, the grammatical principle violates the principle of FSP linearity, i.e., the highest degree of $\mathrm{CD}$ is carried by subject, and the most prominent element comes at the beginning of the sentence (Adam, 2007: 23).

As is noticed in Firbas' ideas, it is confined to linear order. However, this should be taken into consideration in a wider sense by applying other elements (such as inversion, questions, verbs of appearance, passives and so on) from the perspective of non-linear arrangement as it is seen in the given texts.

\section{Methodology}

The issue that is facing us is: what is text organization? In this paper, the important issue is how text organization is formed in thematic progression. This general purpose can be approached from different angles, e.g., structurally, as Harris (1952) does, lexically Michael Hoey, (1983), in terms of clause interrelationship E. Winter, (1977) or functional-systemic values Halliday, (1978), Dik (1978), Mackenzie, (2008), cognitive approach Heine (1997), Langacker, (2008) while the Prague Linguistic Circle aimed at establishing the contribution of language units to the process of communication. Hence, the name of the approach is "functional."

Only a few years ago, one-sidedness of the given theory was complemented by the cognitively (consideration of the external factors, e.g., emotiveness) and pragmatically (intentional reaction of the participants to the initiating part, context or situation) oriented philosophy of communication science the natural complexity of which has remained largely ignored in the relevant theory. And the testing of the potential of the "new-before/without-known" model proves and sets up a reasonable balance between the opposed poles in the continuously debated "scientific pluralism." Our approach is a qualitative (explanatory) one seeking answers to causal facts, as well as to the "what?" and "why?" questions. It is of the explanatory type in that it searches for potential explanations of observed phenomena. In this case, the relevancy and productivity of the "known-before-new" and "new-before/without-known" models in text organization can be evidenced by a more dynamic use of language.

In this paper, theoretical information about textuality and thematic progression has been provided and thematic progression has been tested in various two texts. These two texts have been selected from both in English and Turkish. How thematic progression is formed has been attempted in both of these texts.

As for restricting the belles-lettres functional style data with O.Wilde's and A. Nesin's short stories, it is due to a simple reason: these stories reflect the ways in which 
both the social status and situation force the participants in discourse to influence the choices that are made about text building, i.e., how speakers build new utterances out of pieces of things other people are saying.

\section{Findings}

A small part of thematic progression in O.Wilde's and A. Nesin's short stories has been analyzed below. All the sentences/clauses selected in the short stories have been determined as theme-rheme. The asserted notions in this study have been outlined below the texts.

\section{The Nightingale and the Rose}

$\frac{\text { (1) 'She said that }}{\mathrm{T}} \frac{\text { she }}{\mathrm{T}} \frac{\text { would dance with me }}{\mathrm{R}} \frac{\text { if I brought her }}{\mathrm{R}} \frac{\text { red roses,' }}{\mathrm{R}} \quad \frac{\text { cried the }}{\mathrm{T}}$ young Student; (2) 'but in all my garden there is no red rose.'

\section{$\mathrm{T} \quad \mathrm{T} \quad \mathrm{R}$}

(3) From her nest in the holm-oak tree the Nightingale heard him, (4) and she $\mathrm{T}$ $\mathrm{T} \quad \mathrm{R}$ $\mathrm{T}$

looked out through the leaves, and wondered.

$\mathrm{R}$

(5) 'No red rose in all my garden!' he cried, (6) and his beautiful eyes filled with $\mathrm{R} \quad \mathrm{T} \quad \mathrm{T} \quad \mathrm{R}$

tears. (7)'Ah, on what little things does happiness depend! (8)I have read all that the $\mathrm{R} \quad \mathrm{T} \quad \mathrm{R}$ wise men have written, (9) and all the secrets of philosophy are mine, (10) yet for $\mathrm{R} \quad \mathrm{T} \quad \mathrm{R}$

want of a red rose is my life made wretched.' (11) 'Here at last is a true lover,' said $\mathrm{R}$ $\mathrm{R}$

the Nightingale (12) 'Night after night have I sung of him, though I knew him not: $\mathrm{T}$ $T$ $\mathrm{R}$ $\mathrm{T}$ $\mathrm{R}$

night after night have I told his story to the stars...

$\mathrm{T}$ $\mathrm{R}$

Non-linear directionality leads from most important (or put it otherwise, the discourse-motivated, no matter, it was mentioned or not mentioned before) to less important meanings (i.e., from "rheme" to "theme" or "the theme" is wholly absent). E.g. tears.

"No red roses in all my garden!" He cried and his beautiful eyes filled with 
"No red roses in all my garden!" in this example wholly consists of the previously mentioned elements ("red roses", "my garden") which have been made most prominent, with the addition of intensifiers "no" and "all", the sentence initial position which is normally designed for known information or theme. The non-linearity-based principle of the $1^{\text {st }}$ clause is followed by already the traditionally acknowledged distribution of the thematic and rhematic sections: "and his beautiful eyes" (theme) is completed by the rheme "filled with tears". With reference to our example from O.Wildes's "The Nightingale and the Red Rose", the non-linearly motivated information is compatible with the unidirectional development of the text in clause 2 .

The same assumption holds for "Here at last is a true lover," said the nightingale. Night after night, have I sung of him, though I knew him not: night after night have I told his story to the stars." The problems are essentially alike as those mentioned in example 1: "Here at last is a true lover" as rheme precedes the theme "said the nightingale", both of which are characterized with the inverted word order. As for the following sentence, with its 2 clauses, it is also concerned with non-linear flow of information: the repetition of "night after night" twice as an expressive means has been used here intentionally, to emphasize that young student is under the stress of strong emotion, and even hopelessness and despair.

\section{An Ass the Grand Vizier}

(1)Bir varmıș, bir yokmuș. (2)Evvel zaman içinde, kalbur saman içinde, bir $\mathrm{T}$ $\mathrm{T}$

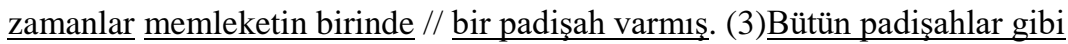
$\mathrm{R}$ $\mathrm{T}$

memleketin birindeki bu padișahın da, //kendi zamanına göre, çalgıcı ve çengilerden $\mathrm{R}$

çifter çifter, beșer onar odalıkları, cariyeleri, ușakları, dalkavukları ve daha falan $\mathrm{R}$

filanları varmıș. (4) Memleketin birindeki bu padișah, her zaman ve her yerdeki $\mathrm{T}$

padișahlar gibi, // açılıș törenlerinde bulunmak, geçit resimlerinde selam vermek, $\mathrm{R}$

başkalarının yazdığı nutukları okumak, seyahat etmek gibi çok önemli memleket $\mathrm{R}$

ișlerinden vakit bulabildiği zamanlarda ava çıkarmıș. (5)Av meraklısı padișah, // yelden $\mathrm{T}$ $\mathrm{R}$ nem kapar cinsten olduğundan, özel ormanında özel olarak yetiştirilmiş, özel $\mathrm{R}$ 
hayvanları vurmak için ava çıkmadan önce, müneccimbașıyı çağırır, $\mathrm{R}$

(6) Bugün hava nasıl olacak? // diye sorarmıș.

$\mathrm{R} \quad \mathrm{T}$

The essay begins with an excursion to the history in terms of a fairy tale using such expressions as "Bir varmış, bir yokmuş. Evvel zaman içinde, kalbur saman içinde, bir zamanlar memleketin birinde bir padişah varmış." To attract the reader's attention from the very first sentence, Aziz Nesin uses the temporal meaning three times: "bir varmış, bir yokmuş" (grammatical narration), "evvel zaman içinde" (lexical devices), and "bir zamanlar" (lexico-grammatical disagreement level), where "bir" denotes not "singleness" but "indefinite/nobody knows when" meaning, to some extent resembling the English expression "once upon a time." Each clause in sentence 1 has its own theme ("bir") and rheme ("varmış"/"yokmuş"), while sentence 2 begins with a diverse background information consisting of 3 parts, the first two of which also demonstrate rhyming unity with different referential meanings: "evvel zaman içinde" takes us to the past before our time while "kalbur saman içinde" makes that time more precise in terms of the season, i.e., the summer, as the time of harvesting and making preparations is specified indirectly through the expression "kalbur saman içinde" (a sieve in the straw). As for the third part of the background information, it, containing the expression "memleketin birinde" (in a part of the country), together with the first two, functions as the known information while "bir padişah", as the topic is specified as the rheme of the sentence.

Textuality of this essay has been provided by different cohesive devices, coherence and contextualization (on account of both linguistic and extra-linguistic types). For example, the sentence initial-positioned topic sentence "bir varmış, bir yokmuş" presupposes that definite information about the existence/appearance of someone (i.e., the topic) will follow. This semantic contribution has been made by the second sentence, while the third one not only depicts the topic (i.e., the padishah), but also provides essential information about the likeness of these padishahs.

\section{Discussion and Conclusion}

The findings of this study demonstrate that, while theme-rheme (given-beforenew) patterns normally occur in both belles-lettres and scientific functional style, the analysis of the information flow in O.Wilde's "The Nightingale and the Rose" and other literary works does not show the tendency assuming "the new always follows the old". Although "given-before-new" principle is used more frequently (especially in scientific English and Legal documents), and is a more operative strategy in language, the cognitive principle underlying our coding system (in accord with the intentional aspect 
of each communication) reveals a strong correlation between mental expenditure, discourse economy, influence of our purpose and feelings on the style of our language use, and coding quantity.

The problematic analysis results (which do not correspond with linear order of "given-before-new" information flow) in the O.Wilde's coding system in "The Nightingale and the Rose" and A. Nesin's "An Ass the Grand Vizier" concerning the identification of new information enable us to claim that word order is almost completely accounted for by pragmatic factors. This also leads us to conclude that even for a language like English, with overwhelming rigid word order structures, the correlation between word order and information structuring may not (of course, in appropriate cases) characterize the language so well as does the relationship between the communicative purpose of the speaker, context-dependent discourse requirement as well as the extent to which the needed material can be realized effectively by the resources of language.

In English (and in other languages as well) the use of these patterns are strongly determined by the functional styles of language, in other words, the subsystems of language such as vocabulary means, syntactical constructions, and phonetics as well as such external factors as situational (de)contextualization, intention of the speaker and other internal syntactic-semantic conditions such as the encoding of syntactic-semantic potential of clause/sentence elements in contributing to how English indicates information status.

Finally, in this paper it is argued that textuality in both languages is a result of flexible strategies, not frozen rules: no interaction is exactly the same or like any other; there is always another, more appropriate way of doing things (i.e., through "givenbefore-new" or "new-before/without-given" patterns). Idiosyncrasy and novelty are always possible and interpretable. But we could also hardly understand each other without creating and using repeatable (i.e., fixed) structural patterns. Consequently, any discourse/text is a system of consistency and flexibility on all levels of its organization. 


\section{Bibliography:}

ADAM, Martin. A Handbook of Functional Sentence Perspective (FSP in Theory and Practice). Chech Republic: Masarykova University, 2007.

ARNOLD, Jennifer E. et al. Information Structure: Linguistic, Cognitive, and Processing Approaches. USA: Wiley Interdisciplinary Reviews Cognitive Science, 4(4), Pp. 403-413. http://doi.org/10.1002/wcs.1234, 2013.

BROWN, Keith et al. Encyclopedia of English Language and Linguistics. Netherlands: Elsevier, 2005.

COLILLI, Paul. Texts: Semiotic Theory. In Encyclopedia of English Language and Linguistics, Ed.: K. Brown. Netherlands: Elsevier, 2006.

DE BEAUGRANDE, Robert and DRESSLER, Wolfgang. Introduction To Text Linguistics. USA: Longman, 1981.

DIK, Simon C. Functional Grammar. Netherland: North-Holland, 1978.

FIRBAS, Jan. Functional Sentence Perspective in Written and Spoken Communication. England: Cambridge University Press, 1992.

HALLIDAY, Michael A.K. and HASAN, Ruqayia. Cohesion in English. London: Longman, 1976.

HALLIDAY, Michael A.K. Language as Social Semiotic: The Social Interpretation of Language and Meaning. London: Edward Arnold, 1978.

HARRIS, Zellig S. Discourse Analysis. USA: Language 28.1, Pp. 1-30, 1952. Press, 1997.

HEINE, Bernd. Cognitive Foundations of Grammar. USA: Oxford University

HENGEVELD, Kees and MACKENZIE, J. Lachlan. Functional Discourse Grammar: A Typologically-Based Theory of Language Structure. USA: Oxford University Press, 2008.

HOEY, Michael. On the Surface of Discourse. London: George Allen and Unwin, 1983. Retrieved from http://www.ucm.es/info/circulo/ no5/downing.htm.

LANGACKER, Ronald W. Cognitive Grammar: A Basic Introduction. USA: Oxford University Press, 2008.

NESIN, Aziz. Memleketin Birinde Öyküler. İstanbul: Nesin Yayıncılık, 2013. 
RZAYEV, Huseynaga. The Communicative Syntax of English. Ankara: Pelikan Yayınları, 2007.

SANDERS, Ted and SANDERS, Jose. Text and Text Analysis in Mey, Concise Encyclopedia of Pragmatics, Ed.: J.L. Mey. Denmark: Elsevier Publishing, 2006.

SCHIFFRIN, Deborah et al. Handbook of Discourse Analysis. USA: Blackwell Publishing, 2001.

WARD, Gregory and BIRNER, Betty J. Information Structure. In Handbook of English Linguistics, Edit.: Bas Aarts and April McMahon. USA: Basil Blackwell. Pp. 291-317, 2006. 1976.

WERLICH, Egon. A text grammar of English. Germany: Quelle \& Meyer, 2006.

WILDE, Oscar. The Nightingale and the Rose. USA: Kessinger Publishing,

WINTER, Eugene. A Clause-Relational Approach To English Texts: A Study Of Some Predictive Lexical Items In Written Discourse. Instructional Science, 6(1), Pp. 1-92, 1977. Retrieved from http://www.jstor.org/stable/23368134 